\title{
31 Promoting educational equity for students from socioeconomically disadvantaged backgrounds
}

\author{
Monica Thielking
}

\section{How to use this policy}

This policy is designed to provide schools with evidence-based strategies to promote educational equity for students from socioeconomically disadvantaged backgrounds. This policy example is intentionally broad and school policy creators are encouraged to build upon and/or delete suggestions below to create a policy that best represents their school.

[To adapt and use this policy, delete or modify the text as indicated]

\section{[INSERT name of school]: Promoting educational equity for students from socioeconomically disadvantaged backgrounds}

\section{Rationale}

All children have the right to go to school and learn, regardless of who they are, where they live or how much money their family has.

(UNICEF, n.d.)

Schools play a critical role in promoting educational equity for all students, including those from socioeconomically disadvantaged backgrounds. Establishing equity in education is a global challenge and will be achieved when children and young people's participation and performance in education is not reliant on or impacted by their socioeconomic background. An example of this, in the Australian context, is The Melbourne Declaration on Educational Goals for Young Australians (Barr et al., 2008), which articulates nationally consistent future directions and aspirations for Australian students and sets two educational goals for Australian schools:

Goal 1: Australian schooling promotes equity and excellence.

Goal 2: All young Australians become successful learners, confident and creative individuals and active and informed citizens. 
Across the globe, it is estimated that 663 million children live in poverty and 617 million children and adolescents around the world are unable to reach minimum proficiency levels in reading and mathematics (UNICEF, n.d.). Unfortunately, in Australia and elsewhere in the world (e.g., Organisation for Economic Cooperation and Development [OECD], 2018a) students from socioeconomically disadvantaged backgrounds continue to underperform against students from more advantaged backgrounds in reading, mathematics and science, and they tend to hold lower ambitions in relation to completing tertiary education (OECD, 2019a; 2019b; 2019c). Moreover, the gap in performance between disadvantaged and advantaged students in Australia is said to represent at least three full years of schooling (OECD, 2018b).

Families facing poverty may struggle to pay for essential school items, and students may experience shame and embarrassment about their lack of uniforms, educational materials and technology, as well as their ability to participate in extracurricular activities. Saunders et al. (2018) propose a consensual approach to understanding deprivation in this context, that is, "children and young people are defined as deprived if they do not have but want items regarded as essential by a majority of their peers" and "for young people, the items include material ('things') like adequate food, appropriate clothing and a quiet place to study, and activities ('doings') like going out with family and friends and on school excursions" (p. 2). Not having things or not being able to do what peers can do can result in students not participating in certain educational activities as they are deprived of certain items due to cost. Poverty and disadvantage have been found to be a key driving factor for why some students disengage from school (Hancock \& Zubrick, 2015) or experience loneliness and psychological distress (Creed \& Reynolds, 2001).

A host of welfare and charitable organisations have also highlighted the high number of students who come to school without the required resources for a full and uncompromised educational experience (e.g., The Smith Family, 2018). Prior to COVID-19, the latest estimates revealed that $13.6 \%$ of Australians were living in poverty (Davidson et al., 2020). The Salvation Army's 2018 Economic and Social Impact Survey (ESIS) of 1,267 people who access their services revealed that more than two out of five households with children are experiencing food insecurity (The Salvation Army, 2018).

Not having access to nutritional food and being hungry at school have a range of psychological, behavioural and learning impacts (Brown, Beardslee \& Prothrow-Stith, 2008). Across Australia, many schools have implemented programs that attempt to mitigate the detrimental impact of hunger on children's outcomes, such as providing breakfast to students before school (Foodbank, 2015). Furthermore, The Smith Family's Learning for Life program has provided over 50,000 students from socioeconomically disadvantaged backgrounds with emotional, practical and financial support to help with their education (The Smith Family, 2018). These and other programs are important, as promoting educational equity for all students is a 


\section{Thielking}

goal that all schools should be aiming for, but one that requires a whole of community effort.

High student attendance has a direct positive effect on student outcomes (ACARA, 2019). However, there is a scarcity of peer-reviewed studies that have evaluated the impact of school-level initiatives aimed to improve the attendance, academic performance, social and emotional wellbeing, and post-secondary educational attainment of students from socioeconomically disadvantaged backgrounds. One systematic review and meta-analysis of the international literature revealed that providing structured supplementary tutoring to students, customising learning to suit a student's learning needs, and employing cooperative peer-assisted learning activities have a significant impact on improving performance in mathematics and reading in disadvantaged student populations (Dietrichson et al., 2017).

\section{Purpose}

The purpose of this policy is to outline the strategies schools can implement to promote educational equity for socioeconomically disadvantaged students.

\section{Scope}

This policy applies to school leadership and teaching staff of [INSERT name of school].

\section{Policy statement}

All students at [INSERT name of school] have an equal right to a full education.

[INSERT name of school] is committed to upholding the United Nations' Convention on the Rights of the Child by recognising "the right of the child to education, and with a view to achieving this right progressively and on the basis of equal opportunity" (Article 28). Opportunity to participate in a full education at [INSERT name of school] refers to all school activities, including classroom learning activities, co-curricular activities, camps, excursions, incursions and school events.

\section{Resourcing teaching staff to effectively teach students from diverse socioeconomic backgrounds}

[INSERT name of school] will invest in specialised teaching skills and interteacher collaborative practices that promote educational equity for all students (Blaise, 2019). Furthermore, school leadership will invest in opportunities for continuous development of teachers to effectively and confidently teach students from diverse socioeconomic backgrounds and ensure equitable access to digital technologies and instructional materials (Thomson \& Hillman, 2019). 


\section{Improving educational performance of socioeconomically disadvantaged students}

[INSERT name of school] does not only believe that all students from socioeconomically disadvantaged backgrounds are able to achieve but is committed to adopting practices and policies to ensure all students from socioeconomically disadvantaged backgrounds are able to achieve (Burnett \& Lampert, 2016).

[INSERT name of school] will employ a "targeted teaching approach" (Goss, Hunter, Romanes \& Parsonage, 2015), whereby student-centred pedagogy, which adapts to the individual learning needs of students, will be employed. Furthermore, student learning data and student feedback will be continuously monitored to inform teaching, as per the targeted teaching approach described by Goss, Hunter, Romanes and Parsonage (2015).

[INSERT name of school] will ensure supplementary tutoring is available to students who require it and encourage and promote peer-assisted learning (Dietrichson et al., 2017).

\section{Engaging families who are experiencing financial hardship}

[INSERT name of school] is a safe and welcoming school that has an opendoor policy for all families in our school community. Students from socioeconomically disadvantaged backgrounds do better when their parents are more involved in and connected to their child's education (Rubie-Davies et al., 2010). Dedicated staff members are in place to support families who are experiencing financial hardship in a discrete and respectful manner. The school can discuss each family's needs, link families to appropriate resources and services and work together to ensure educational equity for all socioeconomically disadvantaged students is achieved.

[INSERT name of school] will document school-specific strategies to:

(1) Communicate to families that your school is a safe and welcoming school that has an open-door policy for all families to discuss the impact of financial hardship on their child's education and their ability to afford school costs (see strategies in Chapter 26).

(2) Support families to obtain the required resources to mitigate the impacts of poverty and financial stress on their child's education.

(3) Ensure families from socioeconomically disadvantaged backgrounds are connected to the school, actively participate in their child's education and feel a sense of belonging at school.

\section{Access and participation}

Socioeconomically disadvantaged students who participate in extracurricular activities have been shown to report higher levels of self-worth than those who 


\section{Thielking}

do not participate in such activities (Blomfield \& Barber, 2011). [INSERT name of school] continuously monitors all aspects of student access and participation in school activities and supplementary instruction and ensures that access and participation are not dependent on a student's ability to afford these activities. [INSERT name of school] supports students' participation in a full education in a respectful and private manner. Where supplementary materials or instruction are provided, it is done so discretely with the informed consent of the student.

The following strategies will be employed to ensure all students are not disadvantaged or cannot partake in an activity or school expectation due to an inability to pay:

\section{Camps, incursions and excursions}

[INSERT name of school] to document school-specific strategies here to promote all students' right to full access and participation in camps, incursions and excursions.

\section{Access to all required learning materials, including information technologies}

[INSERT name of school] to document school-specific strategies here to promote full access to all required learning materials and information technologies.

\section{School uniform}

[INSERT name of school] to document school-specific strategies here to support socioeconomically disadvantaged students' access to a full school uniform.

\section{School fundraisers}

[INSERT name of school] to document school-specific strategies here to limit the (1) number and/or (2) impact of school fundraising activities on families who are experiencing financial hardship.

Links with national charitable organisations that support educational equity for socioeconomically disadvantaged students*

Australia:

- Australian Indigenous Education Foundation: http://www.aief.com.au

- Clontarf Foundation: https://clontarf.org.au

- Foodbank: https://www.foodbank.org.au

- Stars Foundation: https://starsfoundation.org.au

- The Smith Family: https://www.thesmithfamily.com.au 
International:

- Global Coalition to End Child Poverty: http://www.endchildhood poverty.org/

- UNICEF and Sustainable Development Goals: https://www.unicef. org/sdgs

*This list is not exhaustive, and many other foundations and charities exist that may support the unique needs of socioeconomically disadvantaged students in your school.

\section{Links with local charitable organisations that support educational equity for socioeconomically disadvantaged students in your community}

[INSERT name of school] to list local resources here. Useful local resources may be found through your local council's youth services, community hubs or information centres and local voluntary organisations, ensuring that the appropriate Working With Children checks have been completed.

\section{Rating of evidence base}

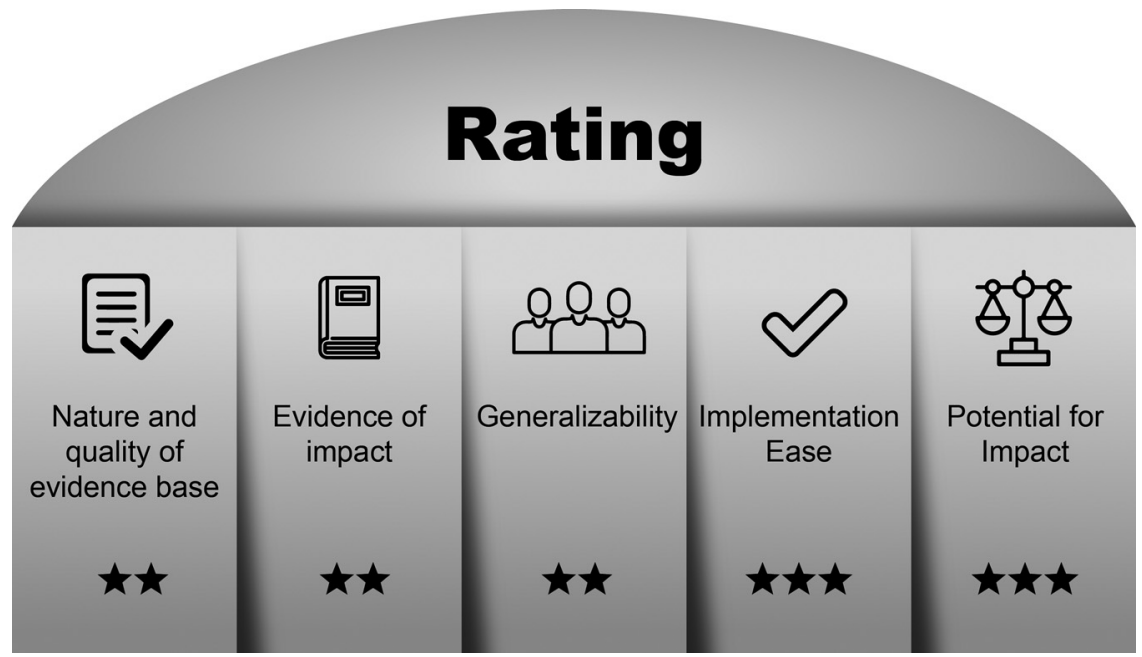

Figure 31.1. Educational Equity for Students from Socioeconomically Disadvantaged Backgrounds Rating of Evidence.

Author Note. The evidence base is mostly Government and Non-Government Organisations' (NGO) reports. Whilst useful, there is a need to increase the quality of the evidence base through more independent, peer-reviewed studies. To implement the policy requires time and commitment from all members of the school community. There is good potential for impact; however, this is reliant on leadership, shared vision and a whole school approach to enact this policy. The creation of collaborative school and community partnerships with a shared aim to improve student outcomes is needed. 


\section{Authorship}

Associate Professor Monica Thielking, Chair Department of Psychological Sciences, Swinburne University of Technology

[INSERT RELEVANT STAFF MEMBERS]

\section{Related policy and documents}

[INSERT RELEVANT POLICY AND DOCUMENTS]

\section{Date of ratification}

This policy was ratified on the [INSERT DATE].

\section{Date of review}

This policy will be reviewed by [INSERT DATE].

\section{Further reading}

Thielking, M., Boie, F. A., Boie, A. A., Flatau, P., \& Teggelove, P. (2017). School psychological practice with students from socio-economically disadvantaged backgrounds. In M. Thielking \& M. Terjesen (Eds.), Handbook of Australian school psychology: Integrating international research, practice, and policy (pp. 553-574). Springer.

Carlisle, E., Hall, S., Fildes, J., \& Plummer, J. (2019). "Working through it": A youth survey report on economically disadvantaged young people. Mission Australia. https://bsllibrary.org.au/general/working-through-it-a-youth-sur vey-report-on-economically-disadvantaged-young-people-mission-australia2-102885/

UNICEF. (2019). Every child learns: UNICEF education strategy 2019-2030.http s://www.unicef.org/sites/default/files/2019-09/UNICEF-education-strategy-2019 -2030_0.pdf

\section{Expert consultation}

Consultation with academic, cultural and content experts may be required to enact the policy. A scoping review of student data, particularly an evaluation of the extent to which student performance is impacted by levels of advantage and disadvantage would be useful in informing the need for this policy. Similarly, student or family input and specific school-level requirements would ensure the policy is relevant and appropriate to the school setting and community. Consultation with teachers, the school psychologist and other wellbeing teams, and the school bursar and "front office" staff in the school would assist in the development of the policy to suit the school's individual needs and context. 


\section{References}

Australian Curriculum, Assessment and Reporting Authority [ACARA]. (2019). The measurement framework for schooling in Australia. ACARA.

Barr, A., Gillard, J., Firth, V., Scrymgour, M., Welford, R., Lomax-Smith, J., Bartlett, D., Pike, B., \& Constable, E. (2008). Melbourne declaration on educational goals for young Australians. Ministerial Council on Education, Employment, Training and Youth Affairs, Australia. http://www.curriculum.edu.au/verve/_resources/National_ Declaration_on_the_Educational_Goals_for_Young_Australians.pdf

Blaise, J. (2019). Overcoming the ddds: A study of Australia's top-performing disadvantaged schools. Centre for Independent Studies. https://www.cis.org.au/app/ uploads/2019/03/rr39.pdf

Blomfield, C. J., \& Barber, B. L. (2011). Developmental experiences during extracurricular activities and Australian adolescents' self-concept: Particularly important for youth from disadvantaged schools. Journal of Youth and Adolescence, 40, 582-594.

Brown, J. L., Beardslee, W. H., \& Prothrow-Stith, D. (2008). Impact of school breakfast on children's health and learning: An analysis of the scientific research. Report commissioned by the Sodexo Foundation. Harvard Medical School and School of Public Health, Center on Hunger and Poverty. http://us.stop-hunger.org/ files/live/sites/stophunger-us/files/HungerPdf/Impact $\% 20$ of $\% 20$ School $\% 20$ Breakfast $\%$ 20Study_tcm150-212606.pdf

Burnett, B., \& Lampert, J. (2016). Teacher education for high-poverty schools in Australia: The national exceptional teachers for disadvantaged schools program. In J. Lampert \& B. Burnett (Eds.), Teacher education for high poverty schools [Education, equity, economy, Vol. 2] (pp. 73-94). Springer International Publishing.

Creed, P. A., \& Reynolds, J. (2001). Economic deprivation, experiential deprivation and social loneliness in unemployed and employed youth. Journal of Community \& Applied Social Psychology, 11(3), 167-178.

Davidson, P., Saunders, P., Bradbury, B., \& Wong, M. (2020). Poverty in Australia 2020: Part 1, overview. ACOSS/UNSW poverty and inequality partnership report no. 3. ACOSS.

Dietrichson, J., Bøg, M., Filges, T., \& Klint Jørgensen, A. M. (2017). Academic interventions for elementary and middle school students with low socioeconomic status: A systematic review and meta-analysis. Review of Educational Research, 87(2), 243-282.

Foodbank. (2015). Foodbank hunger in the classroom report May 2015. https://www. foodbank.org.au/wp-content/uploads/2019/05/Foodbank-Hunger-in-the-ClassroomReport-May-2015.pdf?state $=$ vic

Goss, P., Hunter, J., Romanes, D., \& Parsonage, H. (2015). Targeted teaching: How better use of data can improve student learning. Grattan Institute. https://grattan. edu.au/wp-content/uploads/2015/07/827-Targeted-Teaching.pdf

Hancock, K. J., \& Zubrick, S. (2015). Children and young people at risk of disengagement from school. Commissioner for Children and Young People. https://www.ccyp. wa.gov.au/media/1422/report-education-children-at-risk-of-disengaging-from-schoolliterature-review.pdf

Organisation for Economic Cooperation and Development [OECD]. (2019a). PISA 2018 results (volume I): What students know and can do. OECD Publishing. https:// doi.org/10.1787/5f07c754-en 


\section{Thielking}

Organisation for Economic Cooperation and Development [OECD]. (2019b). PISA 2018 results (volume II): Where all students can succeed. OECD Publishing. https:// doi.org/10.1787/b5fd1b8f-en

Organisation for Economic Cooperation and Development [OECD]. (2019c). PISA 2018 results (volume III): What school life means for students' lives. OECD Publishing. https://doi.org/10.1787/acd78851-en

Organisation for Economic Cooperation and Development [OECD]. (2018a). Equity in education: Breaking down barriers to social mobility. OECD Publishing. https:// doi.org/10.1787/9789264073234-en

Organisation for Economic Cooperation and Development [OECD]. (2018b). Equity in education: Breaking down barriers to social mobility - Australia. OECD Publishing. https://www.oecd.org/pisa/Equity-in-Education-country-note-Australia.pdf

Rubie-Davies, C. M. (2010). Teacher expectations and perceptions of student attributes: Is there a relationship? British Journal of Educational Psychology, 80, 121-135.

Saunders, P., Bedford, M., Brown, J., Naidoo, Y., \& Adamson, E. (2018). Material deprivation and social exclusion among young Australians: A child-focused approach (SPRC report 24/18). Social Policy Research Centre, UNSW. http://doi.org/10. 26190/5bd2aacfb0112

The Salvation Army. (2018). Economic and social impact survey 2018: Feeling the pinch. The Salvation Army. https://www.salvationarmy.org.au/scribe/sites/auesalvos/ files/ESIS_2018_Main_Report.pdf

The Smith Family. (2018). Attendance lifts achievement: Building the evidence base to improve student outcomes. The Smith Family. https://www.thesmithfamily.com.au//media/files/research/reports/education-outcomes-report-attendance-lifts-achievem ent.pdf

Thomson, S., \& Hillman, K. (2019). The reaching and learning international survey 2018. Australian report volume 1: Teachers and school leaders as lifelong learners. Australian Council for Educational Research. https://research.acer.edu.au/cgi/view content.cgi?article $=1006 \&$ context $=$ talis

UNICEF. (n.d.). UNICEF: For every child. UNICEF. https://www.unicef.org/ 